\title{
Study of chemical-based induced bacterial ghost applied in vaccine production
}

\author{
Doan Duy Thanh ${ }^{1 *}$, Tran Xuan Hanh ${ }^{1}$ \\ ${ }^{1}$ National Veterinary Join Stock Company, Vietnam \\ ${ }^{*}$ Corresponding author: duythanh261990@gmail.com
}

\begin{tabular}{|c|c|}
\hline ARTICLE INFO & ABSTRACT \\
\hline $\begin{array}{l}\text { DOI:10.46223/HCMCOUJS. } \\
\text { tech.en.10.1.356.2020 }\end{array}$ & $\begin{array}{l}\text { Introduction: Bacterial ghosts (BGs), known as the empty } \\
\text { cell envelope of gram-negative bacteria lacking cytoplasmic } \\
\text { content yet retaining all unaltered morphological and structural } \\
\text { features of their living counterparts, are widely studied and used } \\
\text { as the platform for the production of the vaccines as well as the } \\
\text { transporting drug and gene delivery. However, the study related to } \\
\text { the creation of BGs based on gene expression is still limited } \\
\text { because of the difference in cell wall structure between } \\
\text { microorganisms. Therefore, in the current study, for the aims to } \\
\text { determine chemicals combination and minimum inhibition } \\
\text { concentration (MIC) to optimize BGs production. }\end{array}$ \\
\hline \multirow[t]{2}{*}{$\begin{array}{l}\text { Received: October } 1^{\text {st }}, 2019 \\
\text { Revised: November } 4^{\text {th }}, 2019 \\
\text { Accepted: December } 6^{\text {th }}, 2019\end{array}$} & $\begin{array}{l}\text { Material and method: Salmonella choleraesuis strain was } \\
\text { collected from NAVETCO company. The study used critical } \\
\text { concentrations from chemical combination to convert salmonella } \\
\text { cells to BGs. Chemicals combination and MIC, temperature, } \\
\text { shaking speed were optimized using Plakett- Burman matrix and } \\
\text { response surface methodology. Cell structure was determined by } \\
\text { using a scanning electron microscope, experimental mice were } \\
\text { vaccinated and challenged with virulence to determine immune } \\
\text { responses of bacterial ghost. }\end{array}$ \\
\hline & $\begin{array}{l}\text { Results: The appropriate chemicals for the production of } \\
\text { BGs biomass were } \mathrm{NaOH} 3.125 \mathrm{mg} / \mathrm{ml} \text {; SDS } 1.15 \mathrm{mg} / \mathrm{ml}, \mathrm{H}_{2} \mathrm{O}_{2} \\
8.79 \mu \mathrm{l} / \mathrm{ml} \text {, ethanol. The observation of morphology, BGs have } \\
\text { remained the structure and shape, which were like the living } \\
\text { microbial cells. }\end{array}$ \\
\hline $\begin{array}{l}\text { Keywords: } \\
\text { Bacterial Ghosts (BGs), } \\
\text { chemical inducers, vaccine }\end{array}$ & $\begin{array}{l}\text { Conclusions: The conditions of BGs production have been } \\
\text { identified to produce large amounts of bacterial ghost biomass to } \\
\text { further application in vaccine production and pharma. }\end{array}$ \\
\hline
\end{tabular}




\section{Introduction}

Most commonly veterinary vaccines are microorganisms that are inactivated by physicals, irradiations, or chemical treatments. During the inactivation process, almost essential bacterial cell wall structures were significantly damaged, resulting in a reduction in immune responses. Although purified sub-unit vaccines were manufactured by microorganisms, they normally have less than normal cells. To fully meet the potential of DNA vaccines, similarly, the development of a vaccine distribution system is required to better activate the mucosal immune response (Jaleta, Mamo, \& Disassa, 2015).

Most currently studies have initially clarified cellular and molecular mechanisms of natural innate immunity. Immune system figures out Pathogen-Associated Molecular Patterns (PAMPs) by Pathogen Recognition Receptors (PRRs), including Toll-Like Receptors (TLRs), C-type lectin-like receptors, etc. These receptors bind micro bio-organism ligands, including cell structures, lipoprotein, protein lipopolysaccharide, DNA, bacterial RNA, viruses, protozoa, and fungi, to activate the different immune response. These PAMPs binding specifically TLR are the basic of adjuvants (Jaleta et al., 2015).

The new strategic applications to develop bacteria are essential in modern veterinary science. Bacterial Ghost is a potential candidature vaccine, and it is an effective modern vaccine distribution system. Although Bacterial ghost is an empty cell envelope, its native structure on the cell wall is still maintained including antigens and bio-bindings. The recombination bacterial ghost system is evaluated as a stable system when it is used for a polyvalent vaccine without cool storage and adjuvants. Additionally, bacterial ghost candidates provide early immune response and controllable (Nik, 2015).

Unfragmented bacterial ghost cell surface provides initial targeting functions of pathogens; thus, it can create immune responses. A bacterial ghost is well-known from a bacterial phage PhiX 174 lysis mechanisms on E.Coli bacteria. Gene expression leads to the formation of the trans-membrane tunnel on the cell wall. However, gene E only impacts on Gram-negative, which may limit the wide application of bacterial ghost. Therefore, an optimal solution is required to create a bacterial ghost that could be applied to Gram-positive and eukaryotes, such as yeast, fungi, blood cells (Abtin et al., 2010; Lubitz, Mayr, \& Lubitz, 2009).

\section{Materials and methodology}

\subsection{Bacterial strain}

Salmonella choleraesuis is a paratyphoid manufactured vaccine strain at Navetco provided by Centre of Veterinary Research - National Veterinary, J.S.C.

The bacterial strain is cultured in $50 \mathrm{ml}$ TSB medium within 72 hours at $37^{\circ} \mathrm{C}$; then centrifugation at 4,000 rpm/min; collected biomass and then washing with 3 times PBS buffer. The obtained bacterial strain was diluted with PBS at the approx. $10^{6} \mathrm{CFU} / \mathrm{ml}$ density.

\subsection{Bacterial ghost preparation}

2.2.1. Determining minimum inhibited concentration (MIC) ( $\mathrm{NaOH}, \mathrm{SDS}, \mathrm{H}_{2} \mathrm{O}_{2}$, temperature, shaking speed) (Amro, 2016)

The determination of minimum inhibited concentration (MIC) of $\mathrm{NaOH}, \mathrm{SDS}, \mathrm{H}_{2} \mathrm{O}_{2}$ followed by Andrew, Mark, and Laura (2006). 
Minimum Growth Concentration (MGC) is defined as the diluted concentration straight after MIC value in which the growth of the first studied bacterial strain is recognized.

2.2.2. Screening the main elements which effect on the Bacterial ghost preparation by Plackette-Burman matrix

Six (6) effect elements were screened for Bacterial ghost preparation at high $(+1)$ and low (-1) value. A total of twelve (12) experiments was carried out based on Plackette-Burman matrix. The result was used for the optimization experiment following RSM-CCD (Jawale \& Lee, 2014).

\section{Table 1}

The elements and value in Plackett-Burman matrix

\begin{tabular}{|c|l|c|c|}
\hline \multirow{2}{*}{ Symbols } & \multirow{2}{*}{ Factors } & \multicolumn{2}{c|}{ Value } \\
\cline { 3 - 4 } & & Low (-1) & High (+1) \\
\hline $\mathrm{X} 1$ & $\mathrm{NaOH}$ & $3.125 \mathrm{mg} / \mathrm{ml}$ & $6.25 \mathrm{mg} / \mathrm{ml}$ \\
\hline $\mathrm{X} 2$ & $\mathrm{SDS}$ & $0.75 \mathrm{mg} / \mathrm{ml}$ & $1.25 \mathrm{mg} / \mathrm{ml}$ \\
\hline $\mathrm{X} 3$ & Shaking speed, temperature & $50 \mathrm{rpm}, 25^{\circ} \mathrm{C}$ & $150 \mathrm{rpm}, 37^{\circ} \mathrm{C}$ \\
\hline $\mathrm{X} 4$ & $\mathrm{CaCO}_{3}$ & $0.35 \mu \mathrm{g} / \mathrm{ml}$ & $1.05 \mu \mathrm{g} / \mathrm{ml}$ \\
\hline $\mathrm{X} 5$ & $\mathrm{H}_{2} \mathrm{O}_{2}$ & $4.68 \mu 1 / \mathrm{ml}$ & $9.375 / \mathrm{ml}$ \\
\hline
\end{tabular}

Source: The researcher's data analysis 


\subsubsection{Bacterial ghost preparation procedure (Jawale \& Lee, 2014)}

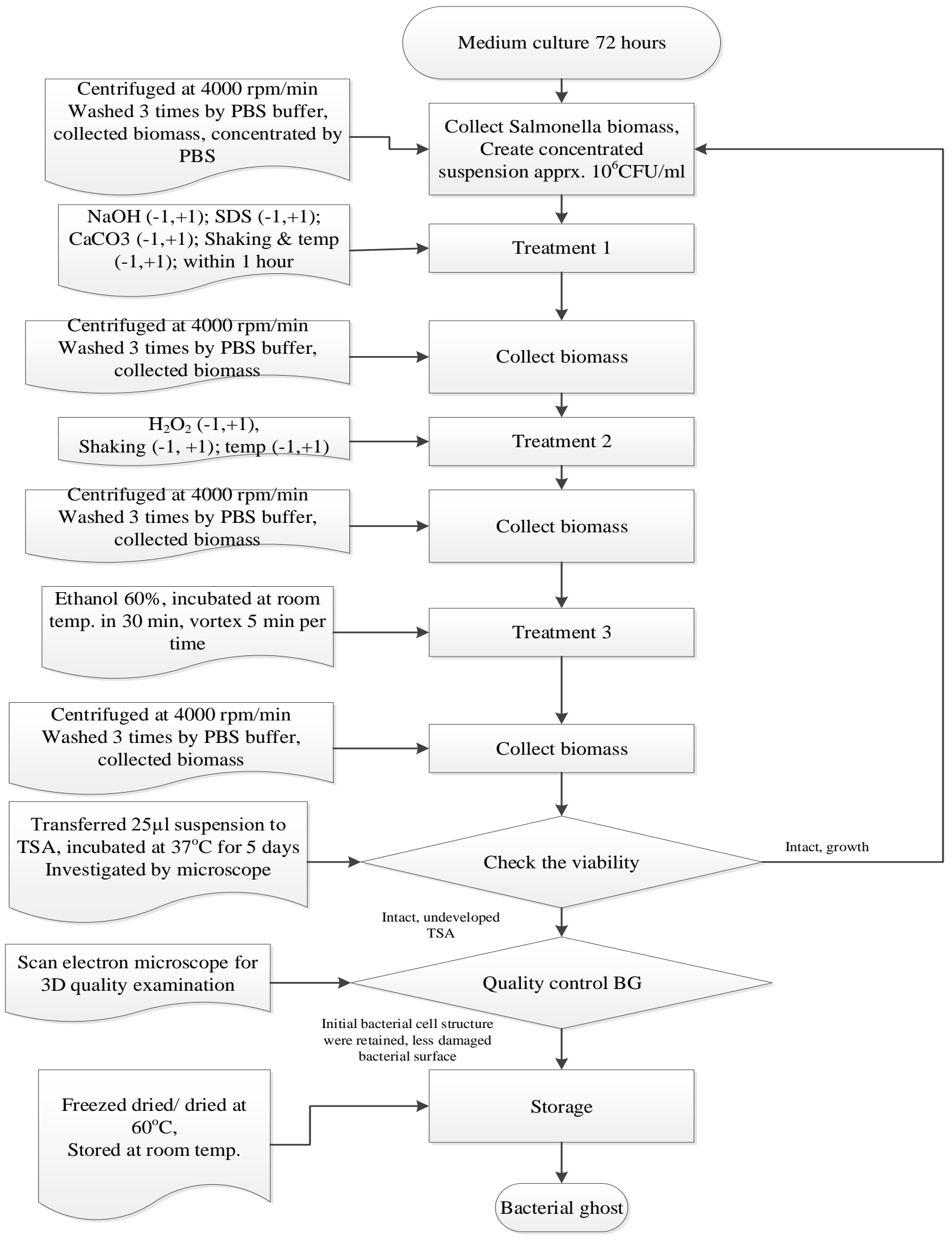

Figure 1. Experimental diagram 
2.2.4. Determining DNA concentration (Abtin et al., 2010) by:

DNA concentration is determined by measuring the absorbance at $260 \mathrm{~nm}$, followed

$$
\mathrm{C}_{\mathrm{DNA}}(\mathrm{ng} / \mathrm{ml})=\mathrm{OD}_{260 \mathrm{~nm}} * 50 * \mathrm{n}
$$

Where: $\mathrm{OD}_{260 \mathrm{~nm}}$ is the absorbance at $260 \mathrm{~nm}$

50 is the converting factor of the solution

$\mathrm{n}$ is the dilution factor.

2.2.5. Determining protein concentration by the spectrometer (Abtin et al., 2010; Amara, Salem-Bekhit, \& Alanazi, 2013)

The protein concentration is determined by measuring the absorbance at $280 \mathrm{~nm}$. BSA (Bovine Serum Albumin) is carried out to construct the calibration curve, $1 \mathrm{mg} / \mathrm{ml} \mathrm{BSA}$ concentration has $\mathrm{OD}=0.67$.

\subsubsection{Evaluate Bacterial ghost biomass quality}

\subsubsection{Evaluation of using a light microscope}

\subsubsection{Evaluation of the viability after Bacterial ghost treatment}

Transfer $25 \mu \mathrm{l}$ suspension in TSA medium, incubate at $37^{\circ} \mathrm{C}$ within 07 days.

\subsection{Optimizing RSM-CCD model}

According to Plackett - Burman screening experiment, the experiment which is carried out to evaluate the optimized values of 3 main elements is studied in 5 levels $(-\alpha,-1,0,+1,+\alpha)$ in 20 CCD experiments followed by $2 n+2 n+6$ ( $n$ is numbers of elements in RSM-CCD). Response Surface Methodology - Central Composite Design is applied in this experimental planning methodology.

\section{Table 2}

The values and elements conducted in RSM

\begin{tabular}{|c|c|c|c|c|c|c|}
\hline \multirow{2}{*}{ Elements } & Studied range & \multicolumn{5}{|c|}{ Level } \\
\cline { 3 - 7 } & & $\mathbf{- \alpha}$ & $\mathbf{- 1}$ & $\mathbf{0}$ & $\mathbf{1}$ & $+\boldsymbol{\alpha}$ \\
\hline $\mathrm{NaOH}$ & $2.059-7.315$ & 2.059 & 3.125 & 4.68 & 6.25 & 7.315 \\
\hline $\mathrm{SDS}$ & $0.579-1.420$ & 0.579 & 0.75 & 1 & 1.25 & 1.420 \\
\hline $\mathrm{H}_{2} \mathrm{O}_{2}$ & $3.079-10.975$ & 3.079 & 4.68 & 7.025 & 9.375 & 10.975 \\
\hline
\end{tabular}

Source: The researcher's data analysis

By using Design Expert 7.0 planning software to figure out the appropriate practical models. From this model, the multi-modal regression model is followed by: 


$$
Y_{i}=b_{0}+\sum_{i=1}^{n} b_{i} x_{i}+\left(\sum_{i=1}^{n} b_{i i} x_{i}\right)^{2}+\sum_{i<j}^{n} b_{i j} x_{i} x_{j}
$$

Where $Y_{i}$ is targeting function, $b_{0}$ is a free factor, $b_{i}, b_{i i}$, and $b_{i j}$ are variables factor of practiced model. The statistical model is significant only and must be complied with statistical standards (Fisher).

\subsection{Scanning BG's surface by SEM}

\subsection{Re-determining the evacuation of DNA medium}

To re-determine the absolute evacuation of intracellular after creating treated bacterial ghosts, DNA bacterial ghost medium is isolated and then is performed by electrophoresis in $1 \%$ gel agarose.

\section{Results}

\subsection{Screening the main elements which effect on the Bacterial ghost}

According to the statistical result, 3 investigation factors (evacuated DNA and protein, bacterial ghost quality) are significantly impacted by $\mathrm{NaOH}$, SDS, and $\mathrm{H}_{2} \mathrm{O}_{2}$ with $\mathrm{p}<0.1$ significant.

\section{Table 3}

Plackett-Burman Matrix experiment result

\begin{tabular}{|c|c|c|c|c|c|c|c|c|}
\hline \multirow{2}{*}{ Exp. } & \multicolumn{5}{|c|}{ Factor } & $\begin{array}{c}\text { DNA } \\
\text { Concentration } \\
\text { (mg/ml) }\end{array}$ & $\begin{array}{c}\text { Protein } \\
\text { Concentration } \\
(\mathbf{m g} / \mathbf{m l})\end{array}$ & $\begin{array}{c}\text { BG quality } \\
\text { (\%) }\end{array}$ \\
\hline 1 & 1 & -1 & -1 & -1 & -1 & 0.028 & 4.15 & 100 \\
\hline 2 & 1 & 1 & -1 & -1 & 1 & 0.029 & 4.33 & 95 \\
\hline 3 & 1 & 1 & 1 & -1 & -1 & 0.026 & 4.02 & 90 \\
\hline 4 & -1 & 1 & 1 & 1 & -1 & 0.028 & 4.21 & 90 \\
\hline 5 & 1 & -1 & 1 & 1 & -1 & 0.025 & 3.89 & 90 \\
\hline 6 & 1 & 1 & -1 & 1 & 1 & 0.025 & 3.89 & 85 \\
\hline 7 & -1 & 1 & 1 & -1 & 1 & 0.028 & 4.21 & 90 \\
\hline 8 & 1 & -1 & 1 & 1 & 1 & 0.028 & 4.15 & 90 \\
\hline 9 & -1 & 1 & -1 & 1 & -1 & 0.029 & 4.21 & 95 \\
\hline 10 & -1 & -1 & 1 & 1 & 1 & 0.026 & 3.96 & 85 \\
\hline 11 & -1 & -1 & -1 & -1 & 1 & 0.029 & 4.27 & 95 \\
\hline 12 & -1 & -1 & -1 & -1 & -1 & 0.025 & 3.89 & 80 \\
\hline
\end{tabular}

Source: Data analysis result of the research 
Table 4

Plackett-Burman matrix factors its impacts

\begin{tabular}{|c|c|c|c|c|c|c|c|c|c|}
\hline \multirow{3}{*}{$\begin{array}{l}\text { Sym- } \\
\text { bol }\end{array}$} & \multirow{3}{*}{ Factor } & \multirow{2}{*}{\multicolumn{2}{|c|}{ Level }} & \multicolumn{6}{|c|}{ Impact factor levels } \\
\hline & & & & \multicolumn{2}{|c|}{ DNA Concentration } & \multicolumn{2}{|c|}{$\begin{array}{c}\text { Protein } \\
\text { Concentration }\end{array}$} & \multicolumn{2}{|c|}{ BG quality } \\
\hline & & $\begin{array}{l}\text { Low } \\
(-1)\end{array}$ & $\begin{array}{l}\text { High } \\
(+1)\end{array}$ & Impact & $\begin{array}{c}\text { Prob > } \\
\text { F }\end{array}$ & Impact & $\begin{array}{c}\text { Prob > } \\
\text { F }\end{array}$ & Impact & $\begin{array}{c}\text { Prob > } \\
\text { F }\end{array}$ \\
\hline $\mathbf{X}_{\mathbf{1}}$ & $\mathrm{NaOH}$ & $\begin{array}{l}3.125 \\
\mathrm{mg} / \mathrm{ml}\end{array}$ & $\begin{array}{c}6.25 \\
\mathrm{mg} / \mathrm{ml}\end{array}$ & 8.333E-006 ${ }^{\mathrm{a}}$ & 0.0185 & $0,059^{\mathrm{a}}$ & $\mathbf{0 , 0 5 1 7}$ & $102.08^{a}$ & 0,0081 \\
\hline $\mathbf{X}_{2}$ & SDS & $\begin{array}{c}0.75 \\
\mathrm{mg} / \mathrm{ml}\end{array}$ & $\begin{array}{c}1.25 \\
\mathrm{mg} / \mathrm{ml}\end{array}$ & 8.333E-006 ${ }^{\mathrm{a}}$ & 0.0185 & $0,059^{a}$ & $\mathbf{0 , 0 5 1 7}$ & $52,8^{a}$ & $\mathbf{0 , 0 3 6 9}$ \\
\hline $\mathrm{X}_{3}$ & $\begin{array}{c}\text { Shaking } \\
\text { speed, } \\
\text { Tem }\end{array}$ & $\begin{array}{c}50 \\
\mathrm{rpm}, \\
25^{\circ} \mathrm{C}\end{array}$ & $\begin{array}{l}150 \\
\mathrm{rpm}, \\
37^{\circ} \mathrm{C}\end{array}$ & $1.048 \mathrm{E}-006^{\mathrm{b}}$ & 0,6122 & $0,015^{\mathrm{b}}$ & 0,672 & $6.85^{b}$ & 0,6202 \\
\hline $\mathrm{X}_{4}$ & $\mathrm{CaCO}_{3}$ & $\begin{array}{c}0.35 \\
\mu \mathrm{g} / \mathrm{ml}\end{array}$ & $\begin{array}{c}1.05 \\
\mu \mathrm{g} / \mathrm{ml}\end{array}$ & $9.583 \mathrm{E}-007^{\mathrm{b}}$ & 0,5903 & $-0,15^{\mathrm{b}}$ & 0,6561 & $8.33^{b}$ & 0,1419 \\
\hline $\mathbf{X}_{5}$ & $\mathrm{H}_{2} \mathrm{O}_{2}$ & $\begin{array}{c}4.68 \\
\mu 1 / \mathrm{ml}\end{array}$ & $\begin{array}{l}9.375 \\
\mu 1 / \mathrm{ml}\end{array}$ & $5.333 \mathrm{E}-006^{\mathrm{a}}$ & 0,0460 & $\mathbf{0 , 0 7 4 ^ { \mathrm { a } }}$ & $\mathbf{0 , 0 3 3 8}$ & $102.08^{a}$ & 0,0081 \\
\hline
\end{tabular}

${ }^{\mathrm{a}} \alpha=0.1$ is significant, ${ }^{\mathrm{b}} \alpha=0.1$ is not significant

Source: The researcher's data analysis

The experiment is designed in accordance with Plackett-Burman model with 5 elements in 12 experiments. Factors like $\mathrm{NaOH}$, SDS, and $\mathrm{H}_{2} \mathrm{O}_{2}$ impact on 3 elements which are investigated with $\mathrm{p}<0.1$ significant. Therefore, 3 mentioned elements are chosen to further evaluate the appropriate concentration based on RSM model, while remaining elements have remained stable based on the highest predicted model.

\subsection{Evaluation of suitable concentration of RSM model result}

\section{Table 5}

The results of RSM model

\begin{tabular}{|c|c|c|c|c|c|c|}
\hline \multirow{2}{*}{ No } & NaOH & SDS & $\mathbf{H}_{2} \mathrm{O}_{2}$ & \multicolumn{3}{|c|}{ Investigation factor } \\
\cline { 2 - 7 } & Level & Level & Level & $\begin{array}{c}\text { DNA } \\
\text { concentration } \\
\mathbf{m g} / \mathbf{m l}\end{array}$ & $\begin{array}{c}\text { Protein } \\
\text { concentration } \\
\mathbf{m g} / \mathbf{m l}\end{array}$ & $\begin{array}{c}\text { BG quality } \\
\%\end{array}$ \\
\hline 1 & -1 & -1 & -1 & 0.02598 & 3.88158 & 80 \\
\hline 2 & 1 & -1 & -1 & 0.02694 & 4.01316 & 95 \\
\hline 3 & -1 & 1 & -1 & 0.02858 & 4.14474 & 95 \\
\hline
\end{tabular}




\begin{tabular}{|c|c|c|c|c|c|c|}
\hline \multirow{2}{*}{ No } & NaOH & SDS & $\mathbf{H}_{2} \mathbf{O}_{2}$ & \multicolumn{3}{|c|}{ Investigation factor } \\
\cline { 2 - 7 } & Level & Level & Level & $\begin{array}{c}\text { DNA } \\
\text { concentration } \\
\text { mg/ml }\end{array}$ & $\begin{array}{c}\text { Protein } \\
\text { concentration } \\
\text { mg/ml }\end{array}$ & $\begin{array}{c}\text { BG quality } \\
\%\end{array}$ \\
\hline 4 & 1 & 1 & -1 & 0.02803 & 4.21053 & 95 \\
\hline 5 & -1 & -1 & 1 & 0.02776 & 4.27632 & 100 \\
\hline 6 & 1 & -1 & 1 & 0.02830 & 4.07895 & 100 \\
\hline 7 & -1 & 1 & 1 & 0.02837 & 4.21053 & 95 \\
\hline 8 & 1 & 1 & 1 & 0.02817 & 4.14474 & 90 \\
\hline 9 & $-\alpha$ & 0 & 0 & 0.02817 & 4.21053 & 90 \\
\hline 10 & $+\alpha$ & 0 & 0 & 0.02830 & 4.14474 & 95 \\
\hline 11 & 0 & $-\alpha$ & 0 & 0.02721 & 3.81579 & 95 \\
\hline 12 & 0 & $+\alpha$ & 0 & 0.02858 & 4.01316 & 100 \\
\hline 13 & 0 & 0 & $-\alpha$ & 0.02673 & 4.01316 & 90 \\
\hline 14 & 0 & 0 & $+\alpha$ & 0.02830 & 4.21053 & 95 \\
\hline 15 & 0 & 0 & 0 & 0.02810 & 4.27632 & 100 \\
\hline 16 & 0 & 0 & 0 & 0.02796 & 4.14474 & 100 \\
\hline 17 & 0 & 0 & 0 & 0.02851 & 4.21053 & 100 \\
\hline 18 & 0 & 0 & 0 & 0.02789 & 4.21053 & 4.27632 \\
\hline 19 & 0 & 0 & 0 & 0.02789 & 4.21053 & 95 \\
\hline 20 & 0 & 0 & 0 & 0.02810 & & \\
\hline
\end{tabular}

Source: Data analysis result of the research

The result is investigated according to RSM model follows: DNA concentration $(0.02598-0.02857 \mathrm{mg} / \mathrm{ml})$, protein concentration $(3.81579-4.27632 \mathrm{mg} / \mathrm{ml})$, BG quality $(80$ $100 \%)$. Based on ANOVA, the targeting functions from DX7 software are followed:

$Y_{1}=0.028+(7.173 E-005) x_{1}+(2.726 E-004) x_{2}+(4.179 E-004) x_{3}-(2.813 E-004) x_{1} x_{2}-(4.007 E-004) x_{2} x_{3}-(2.143 E-004) x_{3}^{2}$

$Y_{2}=4.22-0.013 x_{1}+0.058 x_{2}+0.058 x_{3}-0.058 x_{1} x_{3}-0.058 x_{2} x_{3}-0.095 x_{2}^{2}-0.026 x_{3}^{2}$

$Y_{3}=97.47+1.35 x_{1}+0.62 x_{2}+2,08 x_{3}-2,50 x_{1} x_{2}-2,50 x_{1} x_{3}-3,75 x_{2} x_{3}-1,81 x_{1}^{2}-1.81 x_{3}^{2}$

Where $\mathrm{x} 1, \mathrm{x} 2, \mathrm{x} 3$ are $\mathrm{NaOH}, \mathrm{SDS}$, and $\mathrm{H}_{2} \mathrm{O}_{2}$ value, respectively.

As for DNA $\left(\mathrm{Y}_{1}\right)$, the regression coefficient $\left(\mathrm{R}_{2}\right)$ is 0,9329 , which means there are 93,29\% of the experimental data matching with predicting data based on the model.

Similarly, there are $90,37 \%$ of the experimental data matching with predicting data based on the model for protein concentration $\left(\mathrm{Y}_{2}\right)$ and $77,78 \%$ that of BG quality. 
The response surface represents the interaction of each pair factor which creates maximum response function. Three (3) factor $\mathrm{NaOH}, \mathrm{SDS}$, and $\mathrm{H}_{2} \mathrm{O}_{2}$ are set with evaluation range follows, DNA concentration $(0.02598-0.02857 \mathrm{mg} / \mathrm{ml})$, protein concentration $(3.81579$ - $4.27632 \mathrm{mg} / \mathrm{ml})$, BG quality $(80-100 \%)$. After proceeded by DX7, nine (9) solutions are figured out to match the maximum response function. To obtain the most optimize and appropriate solution, the result must be based on the highest BG quality and maximum DNA and protein simultaneously. Therefore, the first solution is appropriate for the research aim. The optimized value of $\mathrm{NaOH}$, SDS, $\mathrm{H}_{2} \mathrm{O}_{2}$ are $3.125 \mathrm{mg} / \mathrm{ml} ; 1.15 \mathrm{mg} / \mathrm{ml} ; 8.79 \mu 1 / \mathrm{ml}$, respectively. The maximum DNA content is $0.02843 \mathrm{mg} / \mathrm{ml}$, maximum protein concentration is $4.27631 \mathrm{mg} / \mathrm{ml}$, BG quality is $96.91 \%$ based on the predicted model.

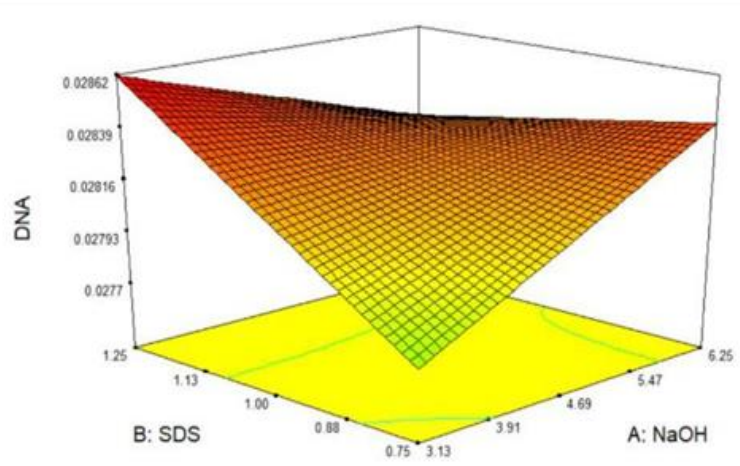

a. DNA response surface concentration, ratio $(\mathrm{NaOH}: \mathrm{SDS})$

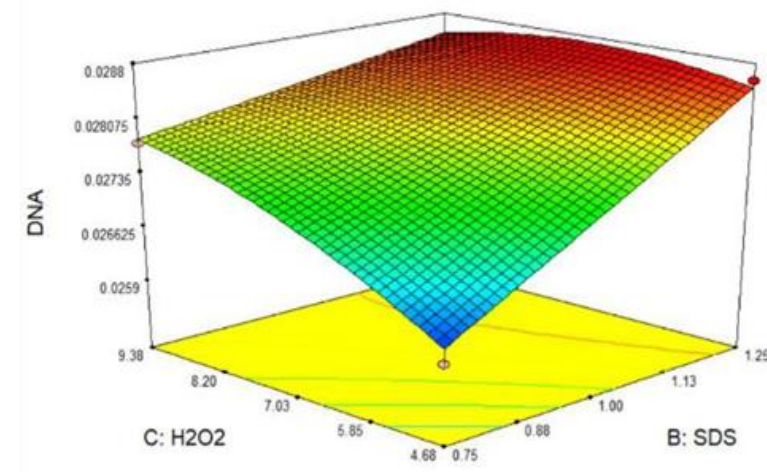

b. DNA response surface concentration, ratio (SDS: $\mathrm{H}_{2} \mathrm{O}_{2}$ )

Figure 2. DNA response surface, ratio $\left(\mathrm{NaOH}: \mathrm{SDS}: \mathrm{H}_{2} \mathrm{O}_{2}\right)$

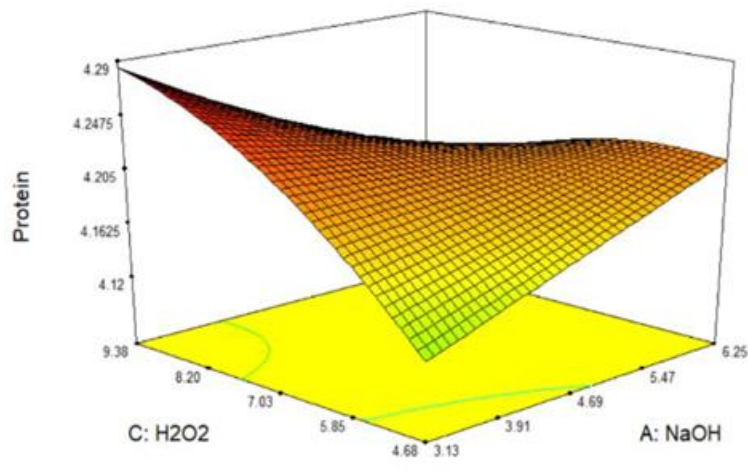

a. Protein response surface concentration, ratio $\left(\mathrm{NaOH}: \mathrm{H}_{2} \mathrm{O}_{2}\right)$

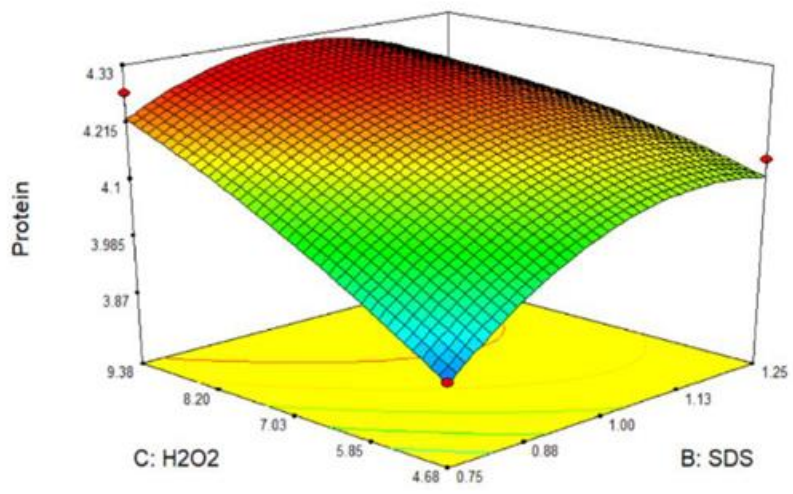

b. Protein response surface concentration, ratio (SDS: $\mathrm{H}_{2} \mathrm{O}_{2}$ )

Figure 3. Protein response surface, ratio $\mathrm{NaOH}$, SDS, and $\mathrm{H}_{2} \mathrm{O}_{2}$ 


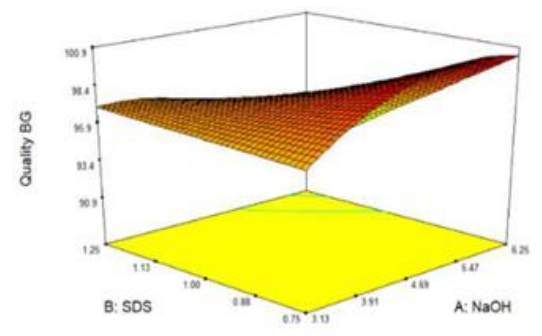

a. BG response surface, ratio (NaOH:SDS)

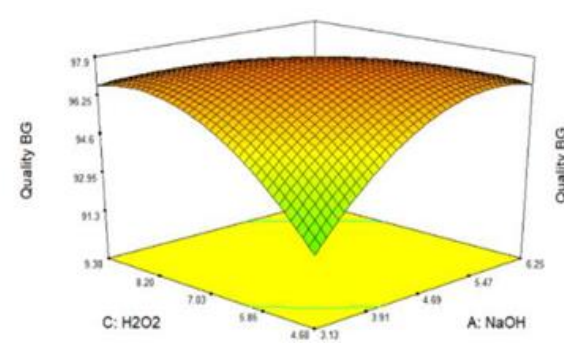

b. BG response surface, ratio $\left(\mathrm{NaOH}: \mathrm{H}_{2} \mathrm{O}_{2}\right)$

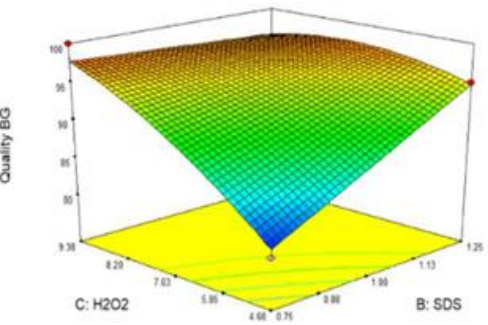

c. BG response surface, ratio (SDS: $\mathrm{H}_{2} \mathrm{O}_{2}$ )

Figure 4. $\mathrm{BG}$ response surface, ratio $\mathrm{NaOH}$, SDS, and $\mathrm{H}_{2} \mathrm{O}_{2}$

\subsection{Scanning of Bacterial ghost surface by SEM results}

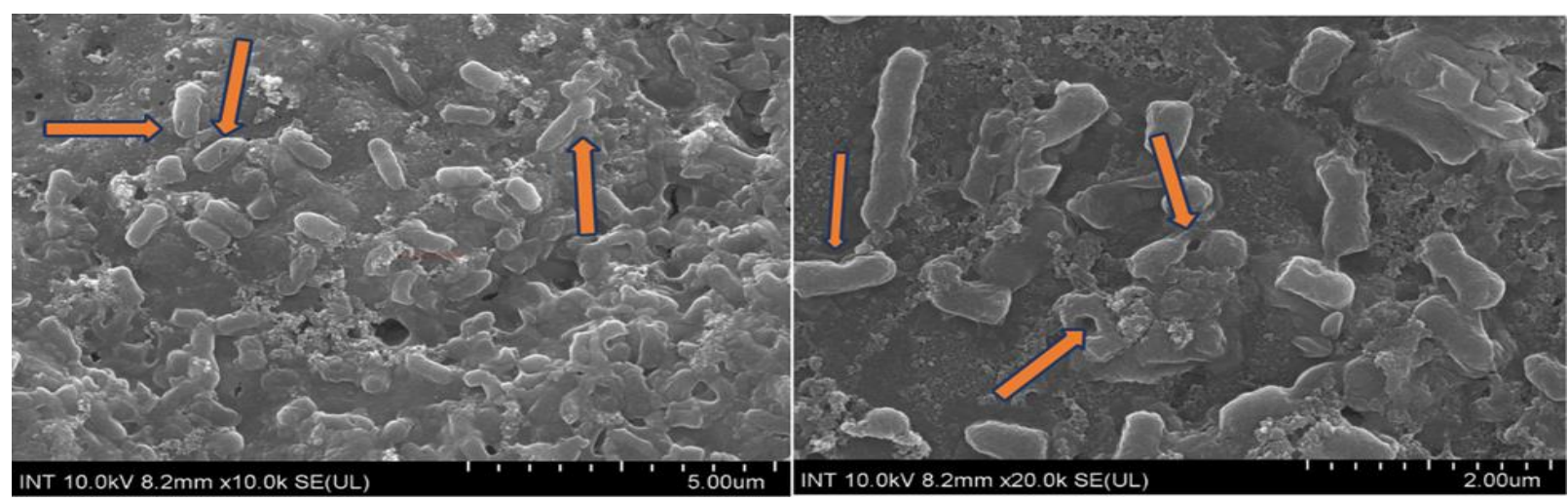

Figure 5. Scanning electron microscope for Bacterial ghost cells

The result shows BG remains its initial cell structure. A tunnel transmembrane is found on the BG surface.

3.4. Agarose electrophoresis result

\begin{tabular}{|c|c|c|c|}
\hline WK & BG & $\begin{array}{c}\text { Sal } \\
(+)\end{array}$ & $\begin{array}{c}\text { PBS } \\
(-)\end{array}$ \\
\hline
\end{tabular}




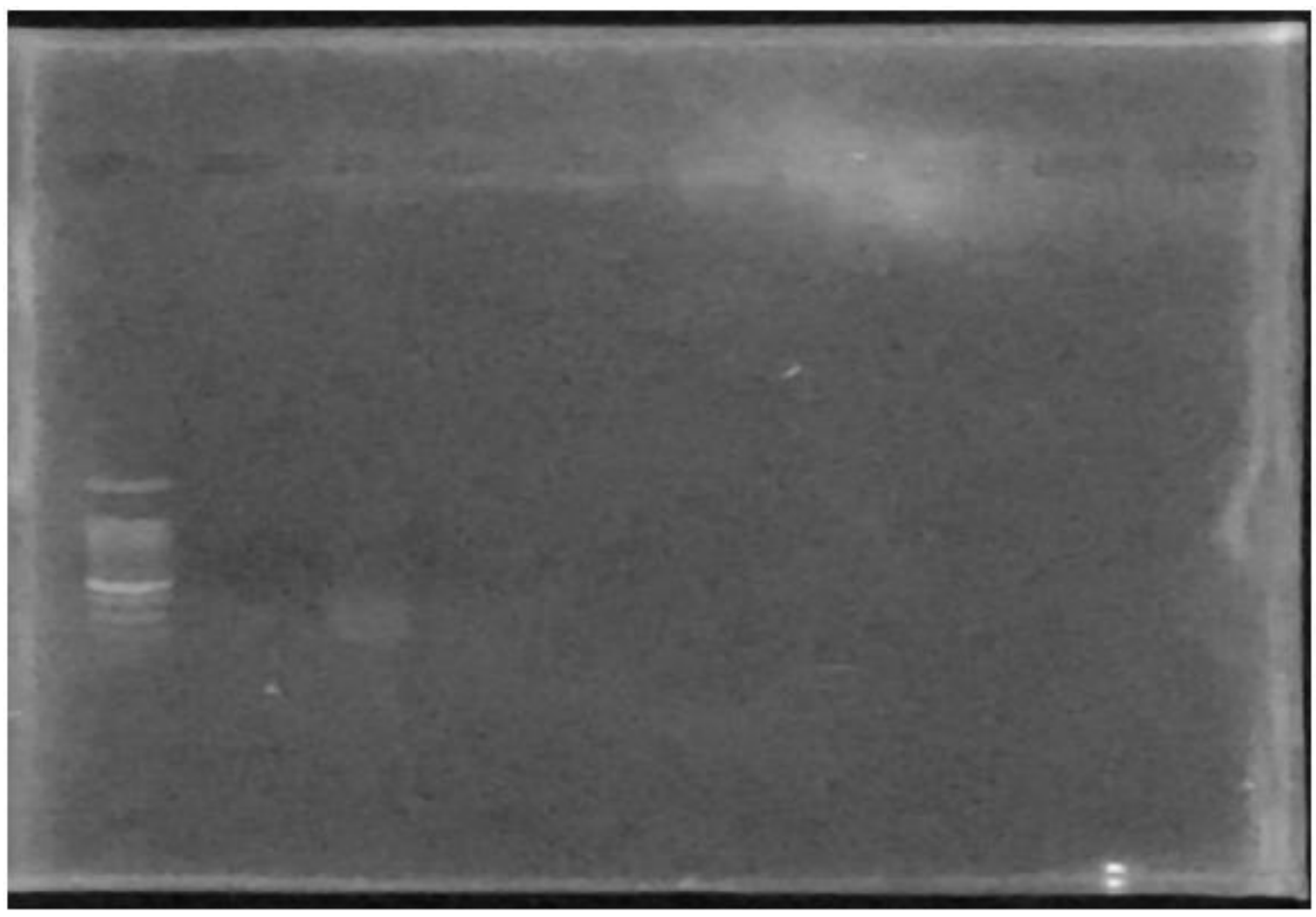

Figure 6. Agarose gel electrophoretic analysis of total DNA extracted from treated cells and non-treated control cells

The DNA electrophoresis of the BG result verifies that BG does not contain any DNA.

\section{Discussion}

Bacterial ghost system for delivery of drugs and biological is still a new concept and a series of detailed systematic studies are required to implement such a system over humans.

- Research has opened up a new approach to BG production;

- From this study, we can reach potential materials such as $(\mathrm{G}+$, yeast, fungi, blood cells); aquaculture.

- Expand BG's application in vaccine production, especially in the veterinary and

\section{Conclusion}

This research is determining the process as well as three (3) main elements are $\mathrm{NaOH}$, SDS, and $\mathrm{H}_{2} \mathrm{O}_{2}$ which impact $\mathrm{BG}$ creation recorded at $3.125 \mathrm{mg} / \mathrm{ml} ; 1.15 \mathrm{mg} / \mathrm{ml} ; 8.79 \mu 1 / \mathrm{ml}$, respectively. Collected BG biomass has remained its 3D structure like the initial bacterial cell, which only present one (1) tunnel strain on the surface wall; additionally, harvested BG biomass does not contain DNA. This research allows enhancing the application of BG which has many applications in vaccine techniques, veterinary as well as aquaculture. Further research should focus on the storage condition, the relationship between the storage duration and immune response, and the increase in immune response when the components as an adjuvant. 


\section{References}

Abtin, A., Kudela, P., Mayr, U. B., Koller, V. J., Mildner, M., Tschachler, E., \& Lubitz, W. (2010). Escherichia coli ghosts promote innate immune responses in human keratinocytes. Biochemical and Biophysical Research Communications, 400(1), 78-82.

Amara, A. A., Salem-Bekhit, M. M., \& Alanazi, F. K. (2013). Sponge-like: A new protocol for preparing bacterial ghosts. The Scientific World Journal, 2013, 1-7. doi:10.1155/2013/545741

Amro, A. A. (2016). The critical activity for the cell wall degrading enzymes: Could the use of the lysozyme for Microbial Ghosts preparation establish emergence oral vaccination protocol? International Science and Investigation Journal, 5(2), 351-369.

Andrew, M. B., Mark, A. W., \& Laura, J. V. P. (2006). Medium plays a role in determining expression of acrB, marA, and soxS in Escherichia coli. Antimicrob Agents Chemother, 50(3), 1071-1074.

Jaleta, H., Mamo, B., \& Disassa, H. (2015). Review on bacterial ghost and its application. International Journal of Microbiological Research, 6(3), 200-210. doi:10.5829/idosi.ijmr.2015.6.3.95282

Jawale, C. V., \& Lee, J. H. (2014). Salmonella enterica Serovar Enteritidis ghosts carrying the Escherichia coli Heat-Labile Enterotoxin B Subunit are capable of inducing enhanced protective immune responses. Clinical and Vaccine Immunology, 21(6), 799-807. doi:10.1128/CVI.00016-14

Lubitz, P., Mayr, U. B., \& Lubitz, W. (2009). Applications of bacterial ghosts in biomedicine. In C. A. Guzmán \& G. Z. Feuerstein (Eds.), Pharmaceutical biotechnology. Advances in experimental medicine and biology (pp. 159-170). New York, NY: Springer.

Nik, H. E. (2015). "Bacterial ghost” as a novel vaccine designing method. Retrieved September 12, 2019, from https://www.prescouter.com/2015/08/bacterial-ghost-as-a-novel-vaccinedesigning-method/ 